\title{
Spawning behavior of the tiger grouper (Mycteroperca tigris) in a Caribbean atoll
}

\author{
Richard M. Starr (1D - Enric Ballesteros • Enric Sala • \\ Josep Maria Llenas
}

Received: 6 December 2017 / Accepted: 7 September 2018 /Published online: 15 September 2018

(C) The Author(s) 2018

\begin{abstract}
Many grouper (Epinephelidae) species aggregate to spawn at specific times of year, at consistent locations, and at specific times of day and phases of the moon. The tiger grouper (Mycteroperca tigris) is widely distributed in the Caribbean Sea and aggregates to spawn just after the full moon. In January and February 2003-2005, we conducted visual surveys of a tiger grouper spawning aggregation at Glover's Reef, Belize. The primary objectives of this study were to describe grouper spawning activities with respect to the timing of the lunar cycle, identify and describe male and female spawning behaviors, and estimate the number of grouper spawning events each day. The peak number of both male and female tiger groupers counted each year occurred from 6 to $10 \mathrm{~d}$ after the full moon. The peak count of males was 1.6-2.2 times greater than the peak count of females. Six categories of male-male and six
\end{abstract}

Electronic supplementary material The online version of this article (https://doi.org/10.1007/s10641-018-0813-4) contains supplementary material, which is available to authorized users.

R. M. Starr $(\bowtie)$

Moss Landing Marine Laboratories, Moss Landing, CA 95039, USA

e-mail: starr@mlml.calstate.edu

E. Ballesteros

Centre d'Estudis Avançats de Blanes (CSIC), 17300 Blanes, Spain

E. Sala

National Geographic Society, Washington, DC 20036, USA

J. M. Llenas

L'Estartit, Spain categories of male-female interactions were identified. All male tiger groupers displayed an ability to rapidly change color; this was often triggered by a close encounter with other male or female tiger groupers. The daily spawning activity was remarkably predictable. The first spawning occurred on average $8.1 \mathrm{~min}$ before sunset, and the last occurred $5.1 \mathrm{~min}$ after sunset. On average, less than half of the females at the spawning site spawned each day, but some females spawned more than once in a given day. Females appeared to choose their mates.

Keywords Tiger grouper $\cdot$ Spawning behavior $\cdot$ Lunar cycle of spawning $\cdot$ Spawning aggregation $\cdot$ Sexual dichromatism

\section{Introduction}

Many commercially important reef fishes form transient spawning aggregations for reproductive purposes (Domeier and Colin 1997). Historically, these aggregations have been quite large, both in space and numbers of fish, but are now much smaller due to extensive fishery removals (Aguilar-Perera 2006; Sadovy de Mitcheson et al. 2013). Aggregating species that have been heavily fished include snappers (Lutjanidae), surgeonfishes and unicornfishes (Acanthuridae), parrotfishes (Labridae), emperor breams (Lethrinidae), and groupers (Epinephelidae).

For most of the larger species of reef fishes, such as the Epinephelid groupers, spawning aggregations are 
seasonal and persist only for short time periods before the fish disperse (Shapiro 1987; Levin and Grimes 2002). Spawning aggregations of many groupers are known to occur in relation to phases of the moon and during only a few months of each year (Rhodes and Sadovy 2002; Matos-Caraballo et al. 2006; Starr et al. 2007). Elaborate courtship behaviors have been observed during spawning events (Gilmore and Jones 1992; Domeier and Colin 1997; Zabala et al. 1997a, b; Hereu et al. 2006; Erisman et al. 2007) and spawning often occurs near sunset, presumably to minimize mortality of the pelagic eggs from visual predators (Lowerre-Barbieri et al. 2011).

The tiger grouper (Mycteroperca tigris) is widely distributed in the Caribbean Sea (Matos-Caraballo et al. 2006). It is a piscivorous fish that inhabits coral reefs from the shoreline to at least $40 \mathrm{~m}$ deep. Tiger groupers are solitary most of the year, feed primarily on reef fishes, and achieve a maximum total length of $1 \mathrm{~m}$ (Heemstra and Randall 1993). Females are smaller than males, which led Smith (1958) to consider them to be protogynous hermaphrodites, with sex reversal from females to males as an animal grows. Although there has been uncertainty about the degree of protogyny in this species (White et al. 2002; Sadovy de Mitcheson et al. 2013), the most recent investigation of tiger grouper histology strongly indicates the occurrence of protogynous hermaphroditism (Caballero-Arango et al. 2013). Similar to other Caribbean grouper species, tiger groupers form spawning aggregations at specific times and locations each year near the time of the full moon in winter months (Sadovy et al. 1994a; Sala et al. 2001; Matos-Caraballo et al. 2006; Nemeth et al. 2006; Erisman et al. 2007).

We learned about a spawning aggregation of tiger groupers at Glover's Reef, Belize, and designed a study to describe their spawning behavior. We used scuba techniques to conduct visual surveys of the spawning aggregation in January and February from 2003 to 2005. Based on behaviors of other grouper species, we hypothesized that tiger grouper spawning would be highly predictable in time and space, and be related to phases of the moon and time of local sunset. Also, we expected to observe elaborate courtship behaviors. The primary objectives of this study were to determine the time of arrival to and emigration from the spawning site, describe grouper spawning activities with respect to the timing of the lunar cycle, identify and describe male and female spawning behaviors, and estimate the number of spawning events each day.

\section{Materials and methods}

\section{Study site}

Glover's Reef ( $\left.16^{\circ} 44^{\prime} \mathrm{N}, 87^{\circ} 48^{\prime} \mathrm{W}\right)$ is the southernmost of three atolls off the coast of Belize. The atoll is located about $45 \mathrm{~km}$ east of the mainland and $30 \mathrm{~km}$ east of the Mesoamerican Barrier Reef. Glover's Reef is an elongated rectangular atoll about $32 \mathrm{~km}$ long and $12 \mathrm{~km}$ wide $\left(384 \mathrm{~km}^{2}\right)$. On the seaward (eastern) side of the reef, the fore-reef contains a spur and groove system of coral ridges that slopes gradually to the drop-off. Most of the fore-reef on the eastern side of the atoll is less than $500 \mathrm{~m}$ wide and the edge of the drop-off occurs at variable depths between 15 and $50 \mathrm{~m}$. The drop-off becomes progressively deeper from the south to the north, where the drop-off falls steeply to a depth of about $1000 \mathrm{~m}$. In some areas there are a series of ledges or terraces that occur at various depths below the drop-off.

The tiger grouper spawning-site we studied is located about $200 \mathrm{~m}$ west of Southwest Caye, in a location that contains a steep drop-off (Fig. 1). At that location, the fore-reef contains a gently sloping mixture of coral patches separated by sand channels $\sim 10 \mathrm{~m}$ wide (Fig. 2). The reef wall trends southwest to northeast and drops precipitously from a depth of about $25 \mathrm{~m}$ to a ledge at about $100 \mathrm{~m}$ deep. The coral species on the reef are typical of those observed in the western Caribbean Sea, and form a vertically and horizontally complex reef structure that provides shelter for a wide variety of species.

\section{Study design}

We used teams of 4-6 scuba divers to observe tiger grouper spawning activity in January and early February of 2003-2005. Combined, we conducted a total of 180 person-dives during the project; each dive was approximately 50-60 min long. Also, in February 2004, trained observers were not available and the manager of the Glover's Reef Marine Reserve counted tiger groupers for us during the February spawning event, without distinguishing males from females.

Each year, prior to the arrival of groupers to the spawning site, we laid out lines on the seafloor to divide the site into six areas, which enabled us to evaluate distributions of male territories and fish movements within the spawning site (Fig. 2 inset). We measured the length and width of the site and estimated water 
Fig. 1 Location of tiger grouper (Mycteroperca tigris) spawning site at Glover's Reef, Belize

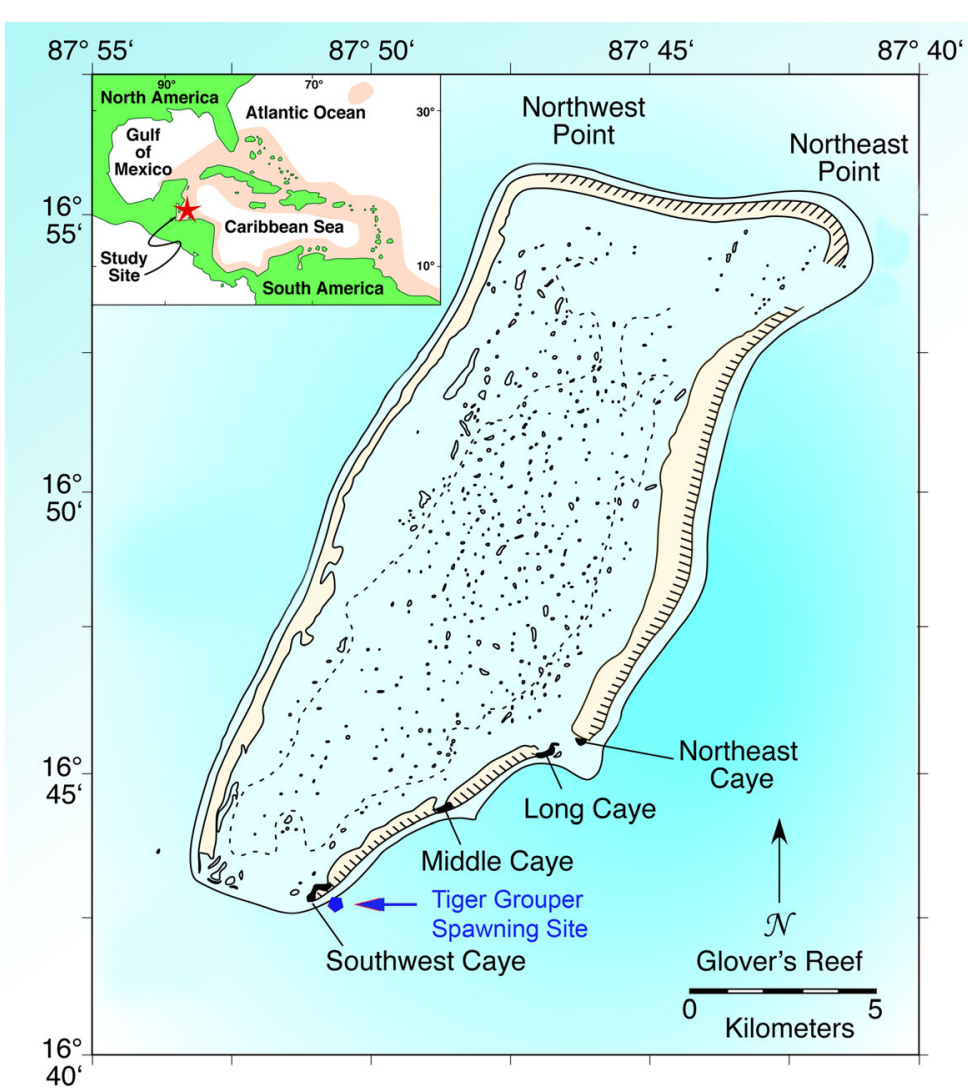

depths along the reef using scuba depth gauges. The spawning site we surveyed is a truncated oval-shape about $56 \mathrm{~m}$ long and $40-50 \mathrm{~m}$ wide $(\sim 0.3 \mathrm{ha})$, and $7 \mathrm{~m}$ high, except on the eastern side, which contains the reef drop-off and wall. The top of the spawning site ranged from 17.2-20.3 $\mathrm{m}$ deep and the base of the site (excluding the southeast facing drop-off) ranged from
22 to $29 \mathrm{~m}$ deep. We visually estimated coral cover by swimming along the reef and noting species and qualitatively estimating abundance (Supplemental material Table 1). Visibility varied between 15 and $25 \mathrm{~m}$ and water temperatures ranged from 24 to $26^{\circ} \mathrm{C}$. Currents were usually light during our studies and flowed from either the northeast to southwest or the reverse direction.
Fig. 2 Schematic of coral ridges that served as spawning locations for tiger grouper (Mycteroperca tigris) spawning from 2003 to 2005. The insert displays a partitioning of the coral reef for purposes of visual counts of groupers

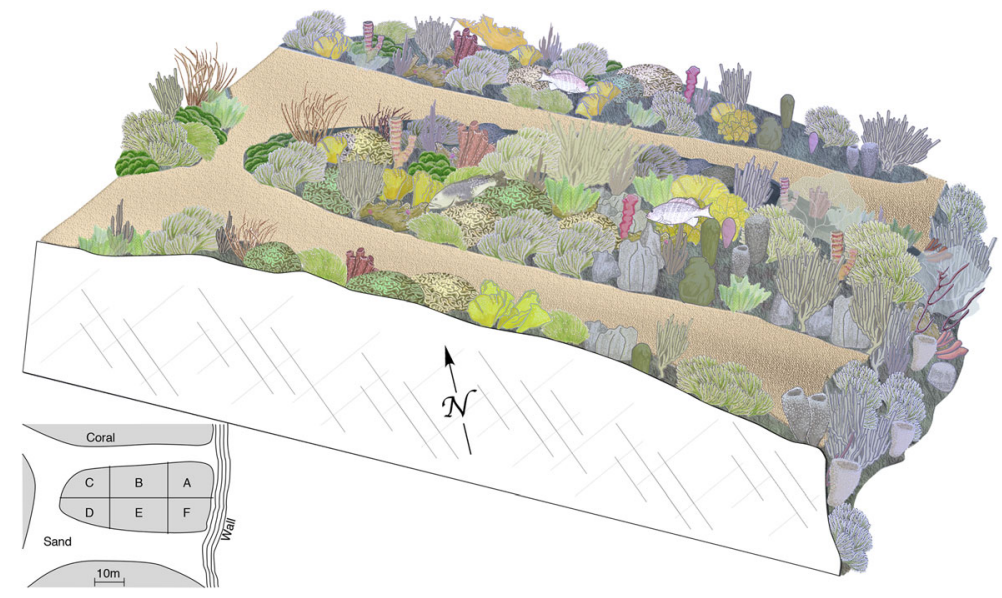


We visited the spawning site on a total of $35 \mathrm{~d}$, both in the morning and just before sunset. We typically started surveys at the spawning site 2-3 d after the full moon and continued surveying until almost all groupers had left the site. We recorded grouper interactions on dive slates and also used video and still cameras to capture behaviors. During the spawning period we visited the site in the morning hours $(\sim 10-11 \mathrm{am})$ to record grouper behaviors, categorize the corals, and record other fishes in the area. Also, we observed grouper interactions at the spawning site each evening for about an hour, from $45 \mathrm{~min}$ before sunset to $15 \mathrm{~min}$ after sunset. First, we visually counted the total number of male and female groupers on site. Males and females, which have similar colorations during most of the year, are sexually dimorphic when in spawning phases (Caballero-Arango et al. 2013), and were easily distinguished by size and coloration patterns. Once the grouper count was made, most divers descended to the bottom and remained stationary in a prescribed section of the reef, as defined by the fixed lines on the bottom. Each diver watched and recorded grouper behaviors on one or two sections of the reef, and except for one or two people, all divers were asked to stay on the bottom to avoid altering grouper behaviors. The divers who did not remain on the bottom were tasked with swimming to nearby reefs to look for and count tiger groupers or were asked to stay higher in water column to observe tiger grouper spawning activity from a different perspective. Most groupers stayed in a specific area, but a few swam throughout the site. To observe those roaming fish, on six occasions we assigned one diver to follow a specific male or female grouper for the entire dive. Divers plotted the track of each grouper along the reef to describe the movements of the roving fish. Dive watches were synchronized and times of all spawning events were recorded. After the dive, behaviors were transcribed from each diver's slate and the numbers of spawning events were reconciled among all divers, to avoid the possibility of having two divers double counting the same event.

Divers with video cameras (Sony TRV 900, MiniDV) attempted to capture as many intraspecific behaviors as possible, thus they turned the cameras on for short periods of time when they saw interactions among male groupers or between males and females. Based on observations by scuba divers, we created six different categories of behavioral interactions for male-male interactions and an additional six behavioral categories for male-female interactions. A single person analyzed the video to ensure consistent categorization of grouper behaviors. The video analyst recorded both the type and duration of interactions among groupers. In addition to the types of behavioral interactions, we attempted to determine the location of the events in the water column. We categorized behavioral events as occurring on $(<$ $1 \mathrm{~m}$ above), $1-3 \mathrm{~m}$ above, or $>3 \mathrm{~m}$ above the seafloor. We only documented active interactions among groupers. There were times when two groupers were in close proximity to each other but displayed no apparent "interest" in each other. These occasions were not counted. Similarly, we did not enumerate interactions between groupers and other species.

\section{Results}

The maximum number of tiger groupers we counted at the spawning site during the spawning period each year ranged from 36 to 111 (Table 1). The peak number of both male and female tiger groupers counted each year occurred from 6 to $10 \mathrm{~d}$ after the full moon (Fig. 3). The peak count of males was 1.6-2.2 times greater than the peak count of females. In 2003 and 2004, when the peak counts of groupers were lower, we saw only a few $(<5)$ tiger groupers on the surrounding reefs, and none of those groupers were observed to spawn. In 2005, however, when the peak count was highest, the surrounding coral reefs contained about $15 \%$ of the fish we counted, and the tiger groupers in those adjacent reefs joined in the spawning on the main reef. That year, we saw one spawning event on the reef to the north of the main site. In February 2004, the manager of the Glover's Reef Marine Reserve observed a peak count of 110 groupers $6 \mathrm{~d}$ after the full moon.

The northeast portion of the site (sector A, Fig. 2) harbored the most groupers; that area contained the most coral cover and was on the up-current side of the reef. When the total number of spawning groupers was high, all portions of the reef were occupied, but the density of tiger groupers was greater near the top of the reef. The largest male groupers we saw occupied territories on the top of the reef (sectors B and E, Fig. 2) and females primarily resided in the deeper areas of sectors $\mathrm{A}$ and $\mathrm{F}$ (Fig. 2). During the evening of peak spawning, densities of tiger groupers at the spawning site ranged from 1.2$4.8 \mathrm{fish} / 100 \mathrm{~m}^{2}$ (Table 1), and averaged $2.8 \mathrm{fish} / 100 \mathrm{~m}^{2}$ when dividing all fish observed by the total site area. 
Table 1 Number of male and female tiger groupers (Mycteroperca tigris) counted at the study site in relation to days after the full moon, the date of the full moon, and estimated maximum density of fish in each sector of the study site on the day of peak spawning numbers in 2005 ( 9 d after full moon). Underlined numbers indicate spawning occurred on that day

\begin{tabular}{|c|c|c|c|c|c|c|c|c|c|c|c|c|c|}
\hline \multirow[b]{2}{*}{ Year } & \multirow[b]{2}{*}{ Sex } & \multicolumn{2}{|c|}{ Moon Date } & \multicolumn{10}{|c|}{ Days After full moon } \\
\hline & & Date & 2 & 3 & 4 & 5 & 6 & 7 & 8 & 9 & 10 & 11 & 12 \\
\hline \multirow[t]{2}{*}{2003} & M & $1 / 18$ & & 0 & 7 & $\underline{24}$ & & $\underline{35}$ & $\underline{40}$ & $\underline{32}$ & $\underline{42}$ & & \\
\hline & $\mathrm{F}$ & & & 0 & 5 & $\underline{12}$ & & $\underline{12}$ & $\underline{18}$ & $\underline{17}$ & $\underline{19}$ & & \\
\hline \multirow[t]{2}{*}{2004} & M & $1 / 7$ & 1 & 3 & 7 & $\overline{17}$ & 34 & $\underline{25}$ & 17 & 7 & 2 & & \\
\hline & $\mathrm{F}$ & & 1 & 2 & 3 & $\overline{2}$ & $\underline{2}$ & $\underline{2}$ & $\overline{5}$ & 3 & 0 & & \\
\hline \multirow[t]{2}{*}{2005} & $\mathrm{M}$ & $1 / 25$ & 37 & 36 & $\underline{49}$ & $\underline{47}$ & $\underline{51}$ & $\underline{46}$ & $\underline{60}$ & $\underline{63}$ & $\underline{48}$ & $\underline{21}$ & 3 \\
\hline & $\mathrm{F}$ & & 12 & 15 & $\underline{21}$ & $\underline{45}$ & $\underline{38}$ & $\underline{42}$ & $\underline{44}$ & $\underline{48}$ & $\underline{28}$ & $\underline{25}$ & 1 \\
\hline \multicolumn{3}{|l|}{2005} & \multirow{2}{*}{\multicolumn{2}{|c|}{$\begin{array}{l}\text { Sector } \\
\text { A } 4.8\end{array}$}} & & & & & & & & & \\
\hline \multicolumn{3}{|c|}{ Max Density (fish/100 $\mathrm{m}^{2}$ ) } & & & \multicolumn{2}{|c|}{ B 4.6} & \multicolumn{2}{|c|}{ C 1.2} & \multicolumn{2}{|c|}{ D 2.4} & E 3.0 & \multicolumn{2}{|c|}{ F 4.6} \\
\hline
\end{tabular}

Large, dominant males arrived the earliest to the spawning site and resided at the apex of the reef, where they created and patrolled an irregular, but apparently well-defined, territory. The territories were about 3-5 m in diameter and were often demarked by a large sponge or soft coral with a vertical relief of $0.5-1 \mathrm{~m}$. Subdominant males occupied slightly smaller territories on the flanks of the main spawning site, and also patrolled the invisible boundaries of their territories. Sneaker males did not create territories, but instead roamed the edges of the main spawning site and waited for opportunities to streak in and join a spawning "cluster".

All male tiger groupers displayed an ability to rapidly change color. During the day we frequently saw males change from their normal grey-tan color with small spots and stripes to a pattern of a green, green and white, or greenish-yellow head with a black body and a large white patch on the ventral-posterior quarter of the fish (Fig. 4a). This color change would occur within seconds and was often triggered by a close encounter with other male or female tiger groupers (Supplemental Video 1). In the late afternoon, all the dominant and sub-dominant males displayed this coloration throughout the presunset spawning activity.

Female groupers were smaller than all males except for the sneaker males, and displayed typical colorations of tiger groupers (Fig. 4b). Females spent the daytime hours quietly residing underneath coral ledges on the flank of the reef. We noticed that several females often would occupy the same area under a coral; however, we did not witness any behavioral interactions among females during the day. During the evening spawning period, the coloration of females was a little different than during the day. Instead of the normal grey-tan color with small stripes and spots, females at the spawning site often displayed a uniform muted-tan color with fewer spots and stripes evident.

\section{Behaviors}

From diver observations and video analyses, we identified six major types of interactions between males (Table 2). Behavior number 1 we describe as "showing color" and occurred when a male grouper
Fig. 3 Frequency distribution, expressed as a kernel density distribution, of the average number of female and male tiger groupers (Mycteroperca tigris) counted at the spawning site each day, relative to days after the full moon

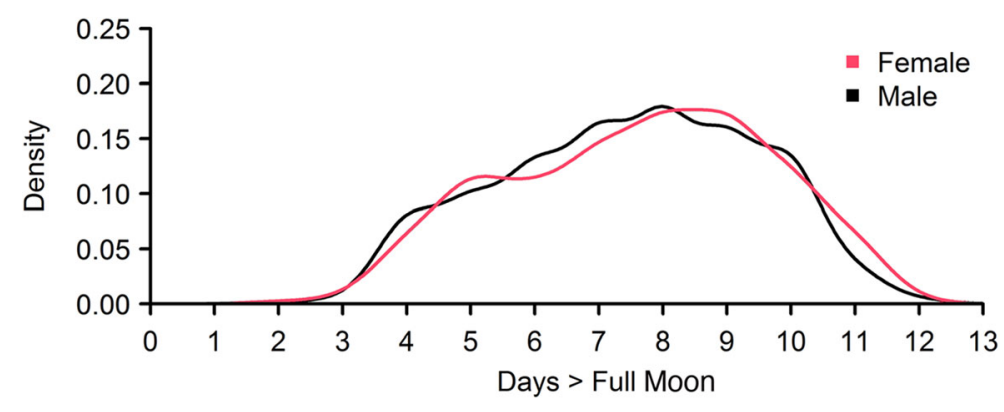


Fig. 4 Tiger grouper

(Mycteroperca tigris) coloration patterns: (a) Males displaying the coloration observed when males are patrolling territories. $\mathbf{b}$ Normal coloration of a female. c Males presenting their white patches. d Two dominant males displaying the "Face to Face" behavior. e Two males in a "Slow roll"

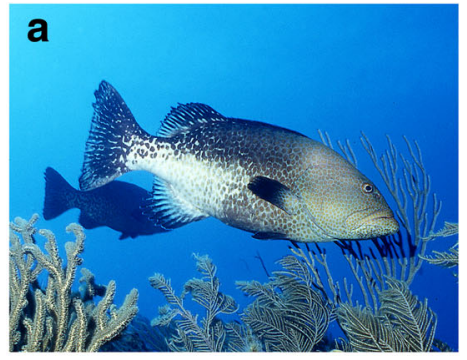

Photo by Enric Ballesteros

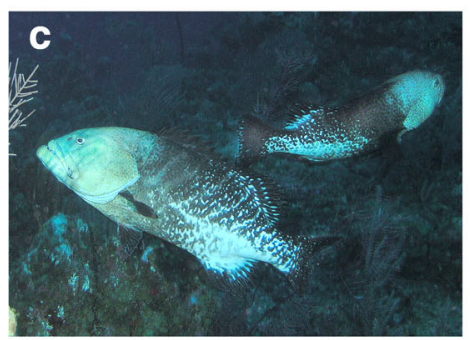

Photo by R. Starr

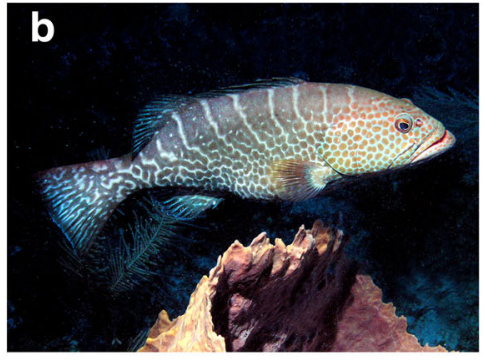

Photo by R. Starr

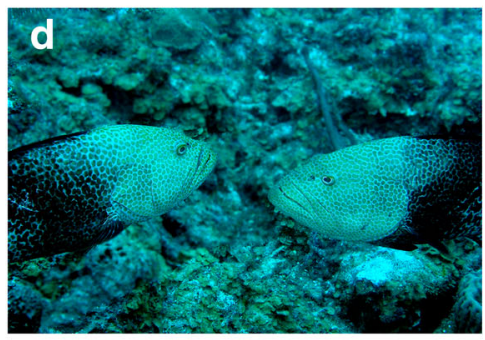

Photo by R. Starr

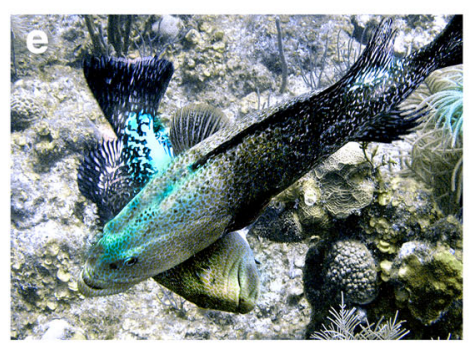

Photo by R. Starr

would swim up to another male and show the prominent white patch on his side to another grouper (Fig. 4c). Behavior number 2 we describe as "face-to-face" and occurred when two fish would face each other less than $20 \mathrm{~cm}$ apart, often with their mouths open (Fig. 4d). Behavior number 3 we describe as "slow roll" and occurred when two fish would swim around each other's body just in front of the pectoral fin, in a ventral-dorsal direction (Fig. 4e). Behavior number 4 we describe as "slow chase" and most frequently happened when a male would slowly swim after another male to ease it out of its territory. Behavior number 5 we describe as "fast chase" and most frequently occurred when a large male would chase a smaller male that had swum into his territory. We never observed the chasing fish catch the chased grouper. Behavior number 6 we describe as "attack from the side" and resulted when one male would attack the side of another male (Supplemental Video 2). Although this behavior was witnessed only infrequently, we saw these attacks result in torn flesh.
We believe this behavior is more common than we witnessed, however, based on observations that many male tiger groupers had fresh bite marks or scars on their sides and heads, and some males had pieces of flesh torn from their side.

We identified six major interactions between males and females (Table 3). Behavior number $1 \mathrm{~F}$ is a "showing color" behavior and occurred when a male grouper would present the prominent white patch on its posterior flank. Behavior number $2 \mathrm{~F}$ we describe as "courting" behavior and occurred when a male (or males) would slowly swim after a female. Often, this behavior would culminate with one of the males swimming close to the female and showing color or "quivering" the way a female does just before spawning (Supplemental Video 3). Behavior number $3 \mathrm{~F}$ is the "slow roll" behavior and occurred when a male grouper would swim up to female and roll around the female's body just in front of the pectoral fin. Behavior number $4 \mathrm{~F}$ we describe as a "chase". 
Table 2 List of behavioral categories that describe observed male-male interactions of spawning tiger groupers (Mycteroperca tigris)
Title

Description of Male-Male Interactions

1 Showing color

2 Face-Face

3 Slow roll

4 Slow chase

$5 \quad$ Fast chase

6 Attack from the Occasionally, a male would attack the side of another male. The attack
side
usually started from less than $2 \mathrm{~m}$ away.
One fish would swim up to another fish and roll partially on its side while turning about 15 degrees off course. The result was a presentation of the prominent white patch on the posterior portion of the male grouper.

Two fish of equal size would face each other near the bottom with their mouths open. They would stay that way until one fish backed up or turned lazily and swam away. This often occurred between two fish occupying neighboring territories.

Two fish of relatively equal size would slowly swim toward each other and commence to turn on their sides and swim around each other's body just in front of the pectoral fin, in a ventral-dorsal direction. The movement resulted in a slow spiral of fish. Sometimes, only the first part of the movement was manifested.

This behavior most frequently happened occurred between males of similar sizes, usually at or near the bottom. In these cases, a male would slowly chase after another male to ease it out of its territory.

This behavior most frequently occurred between males of different sizes, or when a male from a more distant territory swam into a large male's territory. In these cases, a male would rapidly chase after another male. Swimming speeds exceeded all other behaviors except for spawning runs.
Table 3 List of behavioral categories that describe observed male-female interactions of spawning tiger groupers (Mycteroperca tigris)

\begin{tabular}{|c|c|c|}
\hline & Title & Description of Male-Female Interactions \\
\hline $1 \mathrm{~F}$ & Showing color & $\begin{array}{l}\text { A male would swim up to a female and roll partially on its side while } \\
\text { turning about } 15 \text { degrees off its course. The result was a presentation of } \\
\text { the prominent white patch on the posterior portion of the male grouper. }\end{array}$ \\
\hline $2 \mathrm{~F}$ & Courting & $\begin{array}{l}\text { When males and females were in the water column, one to five males } \\
\text { would slowly swim after a female. Often, this behavior would } \\
\text { culminate with one of the males swimming close to the female and } \\
\text { showing color and "quivering" the way a female does just before } \\
\text { spawning. }\end{array}$ \\
\hline $3 \mathrm{~F}$ & Slow roll & $\begin{array}{l}\text { Two fish would slowly swim toward each other and commence to turn } \\
\text { on their sides and swim around each other's body just in front of the } \\
\text { pectoral fin, in a ventral-dorsal direction. The movement resulted in } \\
\text { a slow spiral of fish. }\end{array}$ \\
\hline $4 \mathrm{~F}$ & Chase & $\begin{array}{l}\text { In the water column, a male would occasionally chase after a female. In } \\
\text { these cases, it appeared the reason for the chase was an attempt by } \\
\text { the male to encourage mating activity. }\end{array}$ \\
\hline $5 \mathrm{~F}$ & False spawning & $\begin{array}{l}\text { Several males would surround a female that was stationary in the water } \\
\text { column, in a slightly nose upward orientation similar to the spawning } \\
\text { orientation. The female would then "twitch" in a motion that } \\
\text { approximated the movement that signals the start of spawning, but } \\
\text { she would not follow through with the spawning signal. In those } \\
\text { cases, the males would swirl slowly around each other in a tight ball } \\
\text { while the female swam away. }\end{array}$ \\
\hline $6 \mathrm{~F}$ & Spawning & $\begin{array}{l}\text { Prior to spawning, a female would come to a stop in the water column, } \\
\text { orient herself in approximately a } 45^{\circ} \text { upward orientation and initiate } \\
\text { a "quivering" motion that sent a ripple through her body. At that } \\
\text { time, all males within about } 3-5 \mathrm{~m} \text { would rush toward her to spawn. } \\
\text { Swimming speeds of males were highest at this time. }\end{array}$ \\
\hline
\end{tabular}


Occasionally, a male would chase after a female in an attempt to encourage mating activity. Behavior number $5 \mathrm{~F}$ we classify as a "false spawning" that was initiated by a female. While in a nose-upward position the female would "twitch" in a motion that approximated the "quiver" that signals the start of spawning, but she would not follow through with the spawning event. The difference between the "twitch" and the start of a spawning event was not apparent to us.

Behavior number $6 \mathrm{~F}$ is the actual spawning activity. Prior to spawning, a female would come to a stop in the water column, orient herself in approximately a $45^{\circ}$ upward orientation and initiate a "quivering" motion that sent a ripple through her body. At that time, all males within about 3-5 m would rush toward her to spawn. As males swam towards the female grouper, she would swim 1-2 m upwards before spawning occurred.

We collected $2 \mathrm{~h}$ of video from the dive surveys covering a span of $5 \mathrm{~d}$, and identified 344 separate instances of grouper interactions, 168 different interactions between males and 176 different interactions between males and females. We then calculated the proportion of occurrences each behavior was recorded, relative to the total number of behavioral observations from video, and examined those behaviors as a function of height above the bottom (Fig. 5). The male-male behavior types were evenly distributed, except that the incidence of males chasing off intruders into their territories increased when they were higher off the bottom. The male-female interactions were primarily restricted to the courtship behaviors of showing color and courting, except for the actual spawning events. The courtship behaviors occurred throughout the water column. We saw no evidence of female-female behaviors other than occasionally two females would be side by side, seemingly waiting for the right time to enter the water column during the spawning period, and once we saw two females conduct a slow roll with each other.
Fig. 5 Proportions of different male-male and male-female interactions recorded and delineated from video collected at various heights above the seafloor at the tiger grouper (Mycteroperca tigris) spawning site
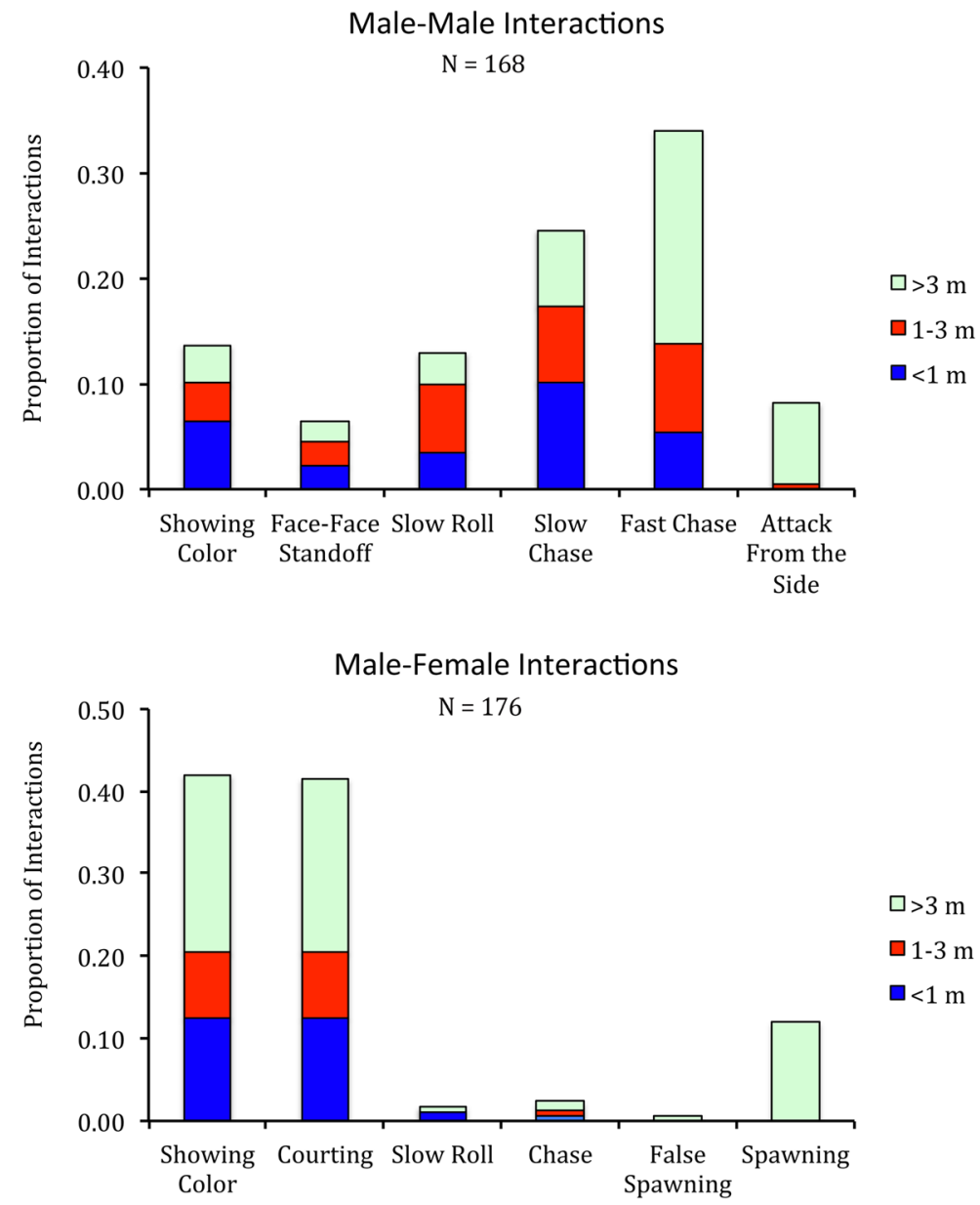
Timing and description of spawning

The numbers of tiger groupers at the spawning site started to increase 2-3 d after the full moon. The pattern of arrival and departure times from the spawning site was similar for male and female tiger groupers (Fig. 3). During our dives during the day ( $1 \mathrm{~h}$ after sunrise to $1 \mathrm{~h}$ before sunset), males established and slowly patrolled their territories. Showing color, face-to-face standoff and slow roll behaviors were the most commonly observed behaviors among males during the day, other behaviors were rarely seen during the day. A few times we saw male groupers exhibit these same behaviors when other fish species came into their territories. Females remained in one spot during the day.

The first spawning event we witnessed occurred $4 \mathrm{~d}$ after the full moon. About $30 \mathrm{~min}$ before sunset, grouper activity at the spawning site started to increase and males would start to come off the seafloor and move up into the water column. The roughly circular territories that males defended on the seafloor expanded upwards in "funnel" shapes. At this time, males patrolled territories that were 5-7 $\mathrm{m}$ wide and 3-5 $\mathrm{m}$ tall. In the water column, males continued to patrol their expanded territories, but because the territories were by then overlapping, there were many antagonistic encounters among male groupers. Attacks from the side and fast chases were common. With all males in the water column, we began to see sneaker males venture from their daytime locations on the surrounding reefs to swim through the overlapping territories established in the water column by the larger males. This often led to a larger male chasing a sneaker male off the reef entirely, before returning to his territory. Interestingly, the males that had occupied adjacent spaces on the bottom during the day were less antagonistic towards each other in the water column than they were towards intruders from other areas. Rather than come off the bottom at one time, females would swim up into the water column, go back down to their coral cover, and then go back up into the water column. Most evenings that we witnessed tiger grouper spawning, all males and females were in the water column and active by $20 \mathrm{~min}$ before sunset (Fig. 6).
After coming off the bottom, individual females swam slowly around the reef top, through most of the male territories, about 3-5 m above the bottom. Usually, females swam through the male territories unmolested. Occasionally, male groupers would approach the females as they entered their territories and exhibit the showing-color and courting behaviors. At times, a male would tilt up at an angle and mimic the false spawning behavior displayed by females. Most often, however, when a female swam into an area occupied by several males, the largest male would attempt to chase all other males away from the female. The male would chase away other males, then follow the female to the edge of his expanded territory, and return to the center if the female did not initiate spawning behavior. These activities became more frenetic with time. The activities of males defending territories became more rapid and more frequent. Also, males increased their efforts to encourage females to spawn by conducting false spawning rises.

Finally, a female would trigger spawning by initiating the quivering motion and swimming upwards. At that point, from 3 to 6 nearby males would rapidly swim to the female in a spawning rush, resulting in the release of eggs and sperm (Fig. 7). These releases would result in a dense cloud of eggs that was immediately preyed upon by a variety of smaller fishes. The spawning site was located at a bend in the reef, so that both the prevailing southwest and northeast currents carried eggs off the reef. Divers following specific groupers counted up to four spawning events (each in a different location) from an individual female tiger grouper in the same night. After a spawning rush, the male groupers returned to their territories (except for sneaker males, which swam off the reef) and the female groupers continued to swim through the male territories at the spawning site. On several occasions, we noticed that the dominant male chased away a sneaker male just before a female initiated a spawning event. In those cases, the large male did not return in time to join in the spawning rush.

The first spawning occurred an average of $8.1 \pm 5.5$ SD $\min , n=14$, before sunset (Table 4). The last spawning event occurred, on average, $13.4 \pm 5.6 \mathrm{SD}$ min after the first spawning and 5.1 $\pm 3.9 \mathrm{SD}$ min after sunset (Table 4). The trend in timing of first and last spawning was towards a later time each night. Each evening, shortly after the last spawning occurred, both males and females swam back down to the bottom. Antagonistic activity among males continued on the 


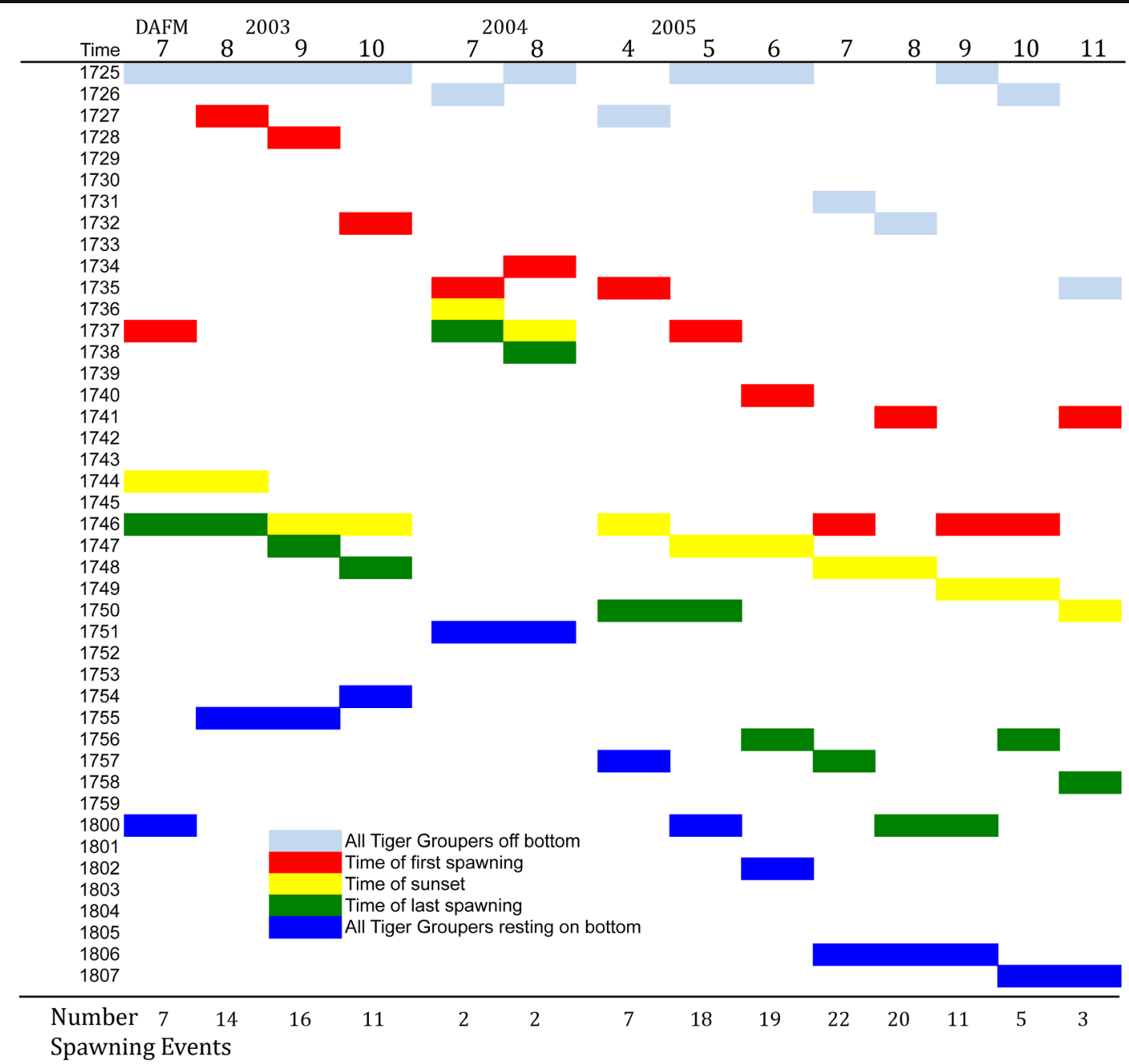

Fig. 6 Timing of tiger grouper (Mycteroperca tigris) vertical movements and spawning times and numbers relative to sunset and days after the full moon (DAFM) at the study site in Belize

seafloor for a few minutes, but then almost all groupers became inactive on the bottom. All groupers were back on the bottom and sedentary by $18 \mathrm{~min}$ after sunset (mean 13.9 $\pm 3.2 \mathrm{SD}$ min, $\mathrm{n}=14$ ). The total time that tiger groupers were active in the water column ranged from 26 to $50 \mathrm{~min}$ and averaged $41.8 \pm 7.0 \mathrm{SD}$ min per evening.

The elapsed time of tiger grouper spawning activity and the number of spawning events observed were related to the number of groupers at the spawning site. A regression analysis yielded a significantly positive relationship $(P=0.03$, Rsquared $=0.35$ ) between the total number of groupers counted at the spawning site and the total time of spawning activity, with total time in minutes equal to $25.1+(0.13 *$ number of groupers counted $)$. Similarly, regression analysis yielded a significantly positive relationship between the number of groupers and the time elapsed between sunset and the last spawning event $(P=0.001$, R-squared $=0.59)$. As would be expected, there also was a positive relationship between the total number of tiger groupers present and the number of spawning events $(P=0.007, \mathrm{R}$-squared $=0.46)$, and the number of female groupers present and the number of spawning events $(P=0.005, \mathrm{R}$-squared $=0.50)$. The number of spawning events equaled $2.98+0.319 *$ the number of females counted. Thus, on average the number of spawning events is predicted to be $43.5 \%$ of the females present each night (Fig. 8). By dividing the number of spawning events observed by the number of females observed, we empirically estimated that, on average, 54\% the females present spawned each night. 


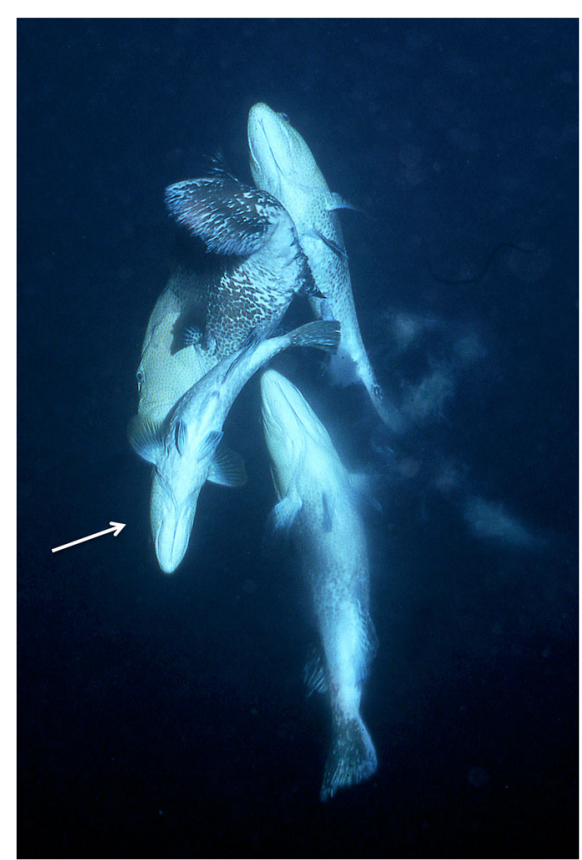

Fig. 7 Group spawning of three male and one female (shown by white arrow) tiger groupers (Mycteroperca tigris). Photo by Enric Ballesteros

The actual number of individual female groupers spawning each night, however, was closer to the predicted value because we noticed multiple spawning events from individual females each evening.

\section{Discussion}

Our results indicated that in Belize, tiger grouper spawning started 2-4 d after the full moon and peaked 6-10 d after the full moon. This timing of spawning related to the lunar cycle is similar to results of other tiger groupers studies in the Gulf of Mexico and Caribbean Sea. Based on histological analyses of gonads collected from tiger groupers off the Yucatan Peninsula, Caballero-Arango et al. (2013) reported that females were actively spawning 7-14 d after the full moon. Similarly, Tuz-Sulub and Brulé (2015) stated that maximum spawning occurred 8-10 d after the full moon in the southern Gulf of Mexico, and White et al. (2002) and Matos-Caraballo et al. (2006) proposed that tiger grouper spawning occurs 4-7 d following the full moon at Vieques Island, Puerto Rico.

In our study, the timing of male and female tiger grouper arrival and departure from the spawning site was remarkably synchronous. We expected that larger males would be the first to arrive at the spawning site so they could set up and defend territories that would give them a selective advantage to the prime spawning locations, but we did not expect females to arrive as early as the males. The largest of the males arrived early and set up territories on the apex of the reef, and the less dominant males chose territories further away from the reef ridge. Small sneaker males arrived latest to the spawning site and were infrequently observed on the main spawning reef. The maximum density of tiger groupers on the spawning site was similar to that reported by Nemeth et al. (2006) for tiger groupers spawning in the U.S. Virgin Islands.

Most researchers studying protogynous groupers have reported sex ratios that are skewed towards females (Beets and Friedlander 1999; Whiteman et al. 2005; Aguilar-Perera 2006), and that the bias is exacerbated in spawning aggregations that are heavily fished (Sadovy et al. 1994b; Coleman et al. 1996). Studies of tiger groupers spawning aggregations, however, have shown the opposite sex bias. The sex ratio of tiger

Table 4 Mean, standard deviation, minimum, and maximum durations of times between the beginning and end of tiger grouper (Mycteroperca tigris) spawning activities

\begin{tabular}{|c|c|c|c|c|c|}
\hline Average Time (min) from: & Mean & $\mathrm{SD}$ & Min & Max & $\mathrm{N}$ \\
\hline Groupers off bottom to first spawning & 11.2 & 5.6 & 2 & 21 & 14 \\
\hline First to last tiger grouper spawning & 13.4 & 5.6 & 2 & 19 & 14 \\
\hline Last spawning until groupers are on bottom & 9.1 & 2.9 & 6 & 14 & 14 \\
\hline Last spawning after sunset & 5.1 & 3.9 & 1 & 12 & 14 \\
\hline First spawning event to sunset & 8.1 & 5.5 & 1 & 19 & 14 \\
\hline Sunset to all groupers on bottom & 13.9 & 3.2 & 8 & 18 & 14 \\
\hline Total tiger grouper spawning time & 41.8 & 7.0 & 26 & 50 & 14 \\
\hline
\end{tabular}




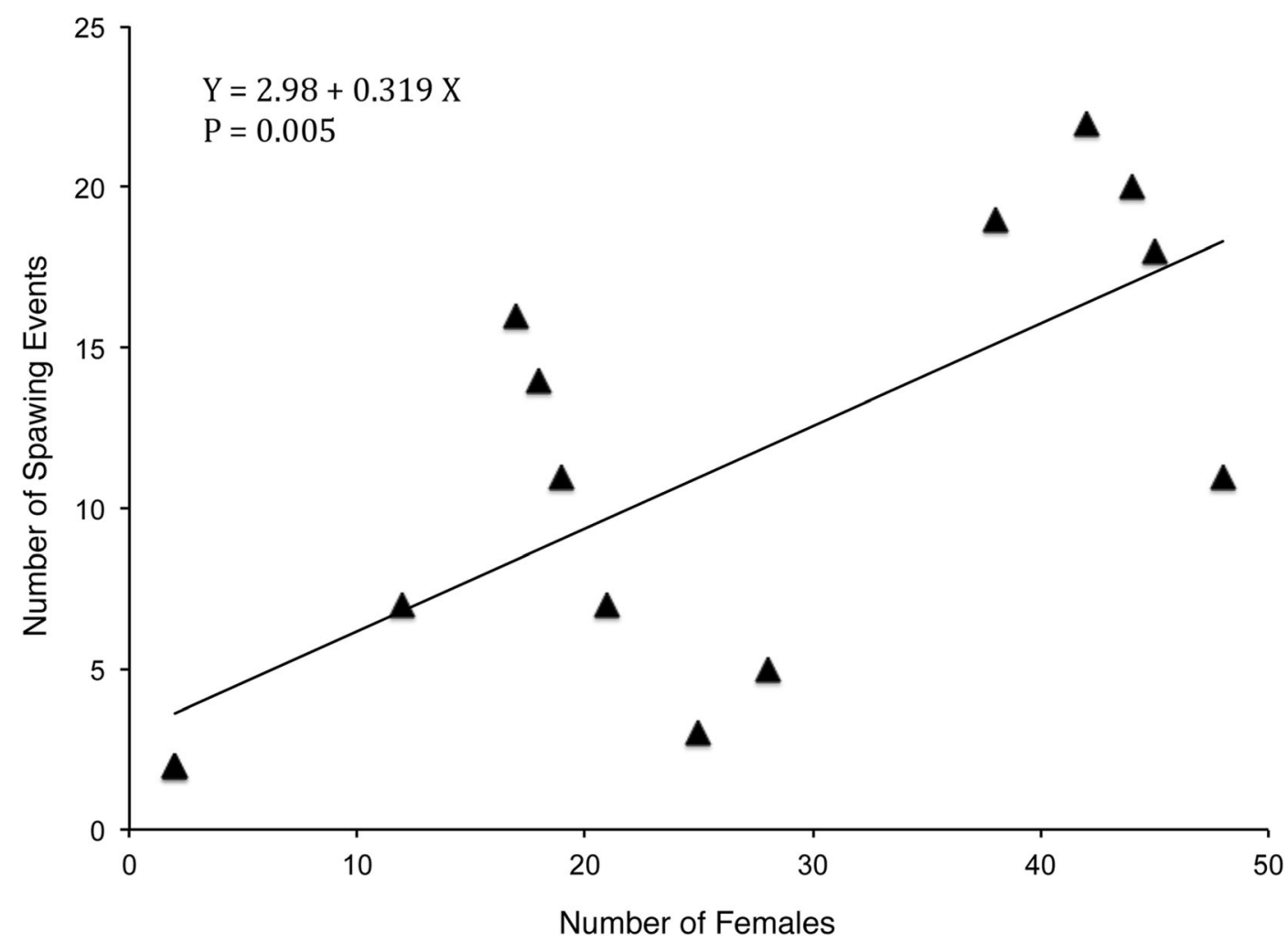

Fig. 8 Relationship between the number of female tiger groupers (Mycteroperca tigris) counted at the spawning site and the number of spawning events observed

groupers in our study ( $>1.5$ males per female) was skewed towards males rather than females. Similarly, White et al. (2002) observed a sex ratio of 1.44 males to 1 female at Vieques Island, Puerto Rico, and the overall sex ratio of a fished tiger grouper population at Bajos del Norte, Mexico was 1.2 males per female (CaballeroArango et al. 2013). As would be expected, in their study the sex ratio was biased toward females in the smaller size-classes and toward males in the larger sizeclasses. This raises the question as to why sex compositions in tiger grouper spawning aggregations are biased towards males when other grouper populations are biased towards females. One possibility is that tiger groupers have not yet received the intense fishing pressure that all other large groupers have experienced. Matos-Caraballo et al. (2006), however, reported that tiger grouper sex ratios in their study increased from 3.7:1 (M:F) in 1995 to $12: 1$ in 1998 , after a period in which tiger grouper abundance decreased, as evidenced by declining catch rates in the fishery. Another possibility for the difference between tiger groupers and other groupers is that the rate of transition from females to males may be faster in this species, perhaps associated with the effectiveness of spawning by sneaker males, thereby increasing the selective advantage to transition early from females to males. Alternatively, the rate of tiger groupers that are born male may be higher than in other grouper species for some unknown reason.

Many grouper species exhibit complex spawning behaviors and sexual dichromatisms during spawning periods (Sala et al. 2003; Schärer et al. 2012; Tuz-Sulub et al. 2006). Domeier and Colin (1997) provided a basis for common description of spawning behaviors. Their descriptions of a spawning rush, group spawning, and streak spawning characterize some of the behaviors we observed in tiger grouper spawning. Sadovy et al. (1994a) were able to provide the first reports of in situ observations of tiger grouper spawning. They saw several different color patterns of tiger groupers on the spawning grounds and reported that males had "a pale head, yellow-tipped, black pectoral fins, and a large white patch on the ventral-posterior quarter of the body". They suggested that the extent and intensity of the colorations varied among individuals and that the 
intensity increased at the time of spawning. Nemeth et al. (2006) also suggested that tiger grouper coloration changed at the spawning aggregations. Their reports match our observations; except that we believe the color variations among different animals were due less to differences among groupers and more because of color changes within each fish. Every male grouper we observed changed color within a matter of seconds, and that color pattern varied, based on the intra-species interaction that was occurring.

We expected to see elaborate courtship and territorial behaviors because of the evolutionary benefits projected for protogynous fishes (Warner 1984; Erisman et al. 2009). A protogynous individual can maximize its lifetime reproductive success by functioning as a female when small and young, and as a male when large and old. Other factors that lead to protogyny are those that reduce male reproductive success at early ages, such as inexperience, territoriality, or female mate selection (Warner 1975).

The male tiger groups in our study courted females, set up territories nearest the actual spawning sites, and vigorously defended their territories, especially against smaller males. The six different male-male behaviors we identified were all related to establishing or defending territories. Despite the vigorous defense of territories, each spawning event contained several smaller males. This group spawning occurred because of the overlapping territories in the water column, and because females chose their mates and initiated spawning at a variety of locations across the reef, not just the ones closest to the territories of the largest males.

We could not tell the reason why females chose to mate when they did, but by following individual females it was clear that females were not just choosing the largest fish. Most likely, this group spawning behavior provides an evolutionary advantage by ensuring that there is competition among sperm that are fertilizing eggs. Sperm contributions by sneaker males are thought to contribute genetic diversity to populations, and interestingly, the success of individual sneaking males may be higher when local male densities are high (Reichard et al. 2004).

Also of interest from an evolutionary perspective is that less than half of the females at the spawning site spawned each night, and some females spawned more than once in a given night. Caballero-Arango et al. (2013) identified tiger groupers as indeterminate spawners that exhibit continuous, asynchronous oocyte development and batch release of mature oocytes, with a mean spawning interval of $2 \mathrm{~d}$. Claro and Lindeman (2003) also indicated that tiger grouper oocytes mature at different rates, suggesting that tiger groupers could potentially spawn seven or eight times over the course of one spawning aggregation. At our study site in 2005, we observed spawning on eight consecutive days. Assuming an average of $43.5 \%$ of the female tiger groupers spawned each night, on average each female would spawn 3.4 times per $8 \mathrm{~d}$ spawning period.

The timing of tiger grouper spawning in our study (6-10 d after the full moon) and the sex ratios skewed towards males is similar to reports from studies of other tiger grouper spawning aggregations in the Caribbean Sea and Gulf of Mexico. On average, less than half of the females in our study spawned each day, but some females spawned more than once in a given day. The timing of the evening spawning activity was remarkably predictable. On average, the first spawning occurred $8.1 \mathrm{~min}$ before sunset, and the last occurred $5.1 \mathrm{~min}$ after sunset. All male tiger groupers displayed an ability to rapidly change color; these color changes coincided with a variety of behaviors triggered by close encounters with other groupers. Females changed to a more muted color at the spawning aggregation and displayed fewer behaviors, but initiated a distinct "quivering" behavior upon selecting their mates, just before beginning a short spawning rush that resulted in a group-spawning event.

Acknowledgements We thank the Belize Fisheries Department for their help with this research. We thank the Summit Foundation, the Wildlife Conservation Society, and the California Sea Grant Program for providing funds for this project. We are indebted to the personnel of the Glover's Reef Research Station for their invaluable help. Special thanks to M. Arman, E. Kisfaludy, N. Lamb, S. Mariani, A. Phillips, M. Sans, L. Uttal, and M. Zabala, who assisted with the diving surveys, and to S. Norris for helping analyze the video we collected. L. McMasters provided graphics support. Also, we thank the two anonymous reviewers who greatly improved this manuscript.

\section{Compliance with ethical standards}

Conflict of interest This research was conducted under the auspices of scientific permits from the Belize Fisheries Department to E. Sala and the Wildlife Conservation Society. All applicable international, national, and/or institutional guidelines for the care and use of animals were followed on this project. This was an observational study of fishes and no animals were handled during this research, and no Institutional Animal Care permits were required for this work. This study was funded by the Summit Foundation, the Wildlife Conservation Society, and the California Sea Grant Program. The authors affirm that there are no conflicts of interest associated with these grants. 
Open Access This article is distributed under the terms of the Creative Commons Attribution 4.0 International License (http:// creativecommons.org/licenses/by/4.0/), which permits unrestricted use, distribution, and reproduction in any medium, provided you give appropriate credit to the original author(s) and the source, provide a link to the Creative Commons license, and indicate if changes were made.

\section{References}

Aguilar-Perera A (2006) Disappearance of a Nassau grouper spawning aggregation off the southern Mexican Caribbean coast. Mar Ecol Prog Ser 327:289-296

Beets J, Friedlander A (1999) Evaluation of a conservation strategy: a spawning aggregation closure for red hind, Epinephelus guttatus, in the US Virgin Islands. Environ Biol Fish 55(1):91-98

Caballero-Arango D, Brulé T, Nóh-Quiñones V, Colás-Marrufo T, Pérez-Díaz E (2013) Reproductive biology of the tiger grouper in the southern Gulf of Mexico. Trans Am Fish Soc 142(1):282-299

Claro R, Lindeman KC (2003) Spawning aggregation sites of snapper and grouper species (Lutjanidae and Serranidae) on the insular shelf of Cuba. Gulf Caribbean Res 14(2):91-106

Coleman FC, Koenig CC, Collins LA (1996) Reproductive styles of shallow-water groupers (Pisces: Serranidae) in the eastern Gulf of Mexico and the consequences of fishing spawning aggregations. Environ Biol Fish 47(2):129-141

Domeier ML, Colin PL (1997) Tropical reef fish spawning aggregations: defined and reviewed. Bull Mar Sci 60:698-726

Erisman BE, Buckhorn ML, Hastings PA (2007) Spawning patterns in the leopard grouper, Mycteroperca rosacea, in comparison with other aggregating groupers. Mar Biol 151: 1849-1861

Erisman BE, Craig MT, Hastings PA (2009) A phylogenetic test of the size-advantage model: evolutionary changes in mating behavior influence the loss of sex change in a fish lineage. Am Nat 174(3):E83-E99

Gilmore GR, Jones RS (1992) Color variation and associated behavior in the Epinepheline groupers, Mycteroperca microlepis (Goode and bean) and M. phenax Jordan and swain. Bull Mar Sci 51(1):83-103

Heemstra PC, Randall JE (1993) FAO species catalogue. Vol. 16. Groupers of the world (family Serranidae, subfamily Epinephelinae). An annotated and illustrated catalogue of the grouper, rockcod, hind, coral grouper and lyretail species known to date. FAO Fish Synop 125(16):382

Hereu B, Diaz D, Pasqual J, Zabala M, Sala E (2006) Temporal patterns of spawning of the dusky grouper Epinephelus marginatus in relation to environmental factors. Mar Ecol Prog Ser 325:189-194

Levin PS, Grimes CB (2002) Reef fish ecology and grouper conservation and management. In: Sale PF (ed) Coral reef fishes, dynamics and diversity in a complex ecosystem. Academic, New York, pp 377-389

Lowerre-Barbieri S, Ganias K, Saborido-Rey F, Murua H, Hunter JR (2011) Reproductive timing in marine fishes: variability, temporal scales, and methods. Mar Coast Fish 3:71-91

Matos-Caraballo D, Posada JM, Luckhurst BE (2006) Fisherydependent evaluation of a spawning aggregation of tiger grouper (Mycteroperca tigris) at Vieques Island, Puerto Rico. Bull Mar Sci 79(1):1-16

Nemeth RS, Kadison E, Herzlieb S, Blondeau J, Whiteman E (2006) Status of a yellowfin grouper (Mycteroperca venenosa) spawning aggregation in the US Virgin Islands with notes on other species. In: Proceedings of the 57th Gulf and Caribbean Fish Institute, vol. 57. St. Petersburg, FL., pp. $543-558$

Reichard M, Smith C, Jordan WC (2004) Genetic evidence reveals density-dependent mediated success of alternative mating behaviours in the European bitterling (Rhodeus sericeus). Mol Ecol 13(6):1569-1578

Rhodes KL, Sadovy Y (2002) Temporal and spatial trends in spawning aggregations of camouflage grouper, Epinephelus polyphekadion, in Pohnpei, Micronesia. Environ Biol Fish 63:27-39

Sadovy de Mitcheson Y, Craig MT, Bertoncini AA, Carpenter KE, Cheung WWL, Choat JH, Cornish AS, Fennessy ST, Ferreira BP, Heemstra PC, Liu M, Myers RF, Pollard DA, Rhodes KL, Rocha LA, Russell BC, Samoilys MA, Sanciangco J (2013) Fishing groupers towards extinction: a global assessment of threats and extinction risks in a billion dollar fishery. Fish Fish 14:119-136

Sadovy Y, Colin PL, Domeier ML (1994a) Aggregation and spawning in the tiger grouper, Mycteroperca tigris (Pisces: Serranidae). Copeia 1994(2):511-516

Sadovy Y, Rosario A, Roman A (1994b) Reproduction in an aggregating grouper, the red hind, Epinephelus guttatus. Environ Biol Fish 41(1-4):269-286

Sala E, Ballesteros E, Starr RM (2001) Rapid decline of Nassau grouper spawning aggregations in Belize: fishery management and conservation needs. Fisheries 26: 23-30

Sala E, Aburto-Oropeza O, Paredes G, Thompson G (2003) Spawning aggregations and reproductive behavior of reef fishes in the Gulf of California. Bull Mar Sci 72(1):103-121

Schärer MT, Nemeth MI, Mann D, Locascio J, Appeldoorn RS, Rowell TJ (2012) Sound production and reproductive behavior of yellowfin grouper, Mycteroperca venenosa (Serranidae) at a spawning aggregation. Copeia 2012(1): 135-144

Shapiro DY (1987) Reproduction in groupers. In: Polovina JJ, Ralston S (eds) Tropical snappers and groupers: biology and fisheries management. Westview Press, Boulder, pp 295-327

Smith CL (1958) The groupers of Bermuda. In J.L. Bardach, C.L. Smith, and D.W. Menzel. Bermuda Fish. Res. Prog. Final Rpt., Bermuda Trade Development board, Hamilton, Bermuda. 59 p. From Fish Base: http://www.fishbase.org 
Starr RM, Sala E, Ballesteros E, Zabala M (2007) Spatial dynamics of the Nassau grouper Epinephelus striatus in a Caribbean atoll. Mar Ecol Prog Ser 343:239-249

Tuz-Sulub A, Brulé T (2015) Spawning aggregations of three protogynous groupers in the southern Gulf of Mexico. J Fish Biol 86(1):162-185

Tuz-Sulub A, Brule T, Cervera-Cervera K, Espinoza-Mendez JC (2006) Evidence for sexual dichromatisms in spawning aggregations of yellowfin grouper Mycteroperca venenosa and tiger grouper Mycteroperca tigris from the southern Gulf of Mexico. J Fish Biol 69(6):1744-1755

Warner RR (1975) The adaptive significance of sequential hermaphroditism in animals. Am Nat 109(965):61-82

Warner RR (1984) Mating behavior and hermaphroditism in coral reef fishes. Am Sci 72:128-136

White DB, Wyanski DM, Eleby BM, Lilyestrom CG (2002) Tiger grouper (Mycteroperca tigris): profile of a spawning aggregation. Bull Mar Sci 70:233-240
Whiteman EA, Jennings CA, Nemeth RS (2005) Sex structure and potential female fecundity in a Epinephelus guttatus spawning aggregation: applying ultrasonic imaging. J Fish Biol 66(4):983-995

Zabala M, Louisy P, Garcia-Rubies A, Gracia V (1997a) Sociobehavioral context of reproduction in the Mediterranean dusky grouper Epinephelus marginatus (Lowe, 1834) (Pisces, Serranidae) in the Medes Islands marine reserve (NW Mediterranean, Spain). Sci Mar 61:79-89

Zabala M, Garcia-Rubies A, Louisy P, Sala E (1997b) Spawning behavior of the Mediterranean dusky grouper Epinephelus marginatus (Lowe, 1834) (Pisces Serranidae) in the Medes Islands marine reserve (NW Mediterranean, Spain). Sci Mar 61:65-77 